HNF-2249

\title{
1997 Project of the Year PUREX Deactivation Project
}

Prepared for the U.S. Department of Energy

Assistant Secretary for Environmental Management

\section{RECORD COPY}

Approved for public release; distribution is unlimited 
LEGAL DISCLAIMER

This report was prepared as an account of work sponsored by an agency of the United States Government. Neither the United States Government nor any agency thereof, nor any of their employees, nor any of their contractors, subcontractors or their employees, makes any warranty, express or implied, or assumes any legal liability or responsibility for the accuracy, completeness, or any third party's use or the results of such use of any information, apparatus, product, or process disclosed, or represents that its use would not infringe privately owned rights. Reference herein to any specific commercial product, process, or service by trade name, trademark, manufacturer, or otherwise, does not necessarily constitute or imply its endorsement, recommendation, or favoring by the United States Government or any agency there of or its contractors or subcontractors. The views and opinions of authors expressed herein do not necessarily state or reflect those of the United States Government or any agency thereot.

This report has been reproduced from the best available copy. Available in paper copy and microfiche.

Available to the U.S. Department of Energy and its contractors from

U.S. Department of Energy

Office of Scientific and Technical Information (OSTI)

P.O. Box 62

Oak Ridge, TN 37831

(615) $576-8401$

Avalable to the public from the U.S. Department of Cornmerce National Technical Information Service (NTIS)

5285 Port Royal Road

Springfield, VA 22161

(703) $487-4650$

Printed in the United States of America

DISCLM-1.CHP (8-95) 
HNF-2249

\section{Project of the Year PUREX Deactivation Project}

R. W. Bailey

$B \& W$ Hanford Company

Date Published

February 1998

Prepared for the U.S. Department of Energy

Assistant Secretary for Environmental Management 


\section{RELEASE AUTHORIZATION}

Document Number: HNF-2249, Rev. 0

Document Title: 1997 Project of the Year PUREX Deactivation Project

Release Date: $\quad 2 / 13 / 97$

This document was reviewed following the procedures described in WHC-CM-3-4 and is:

APPROVED FOR PUBLIC RELEASE

WHC Information Release Administration Specialist:

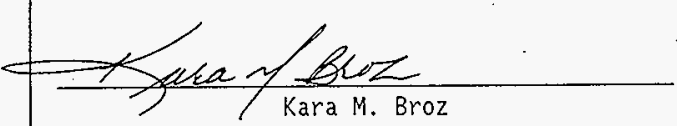

February 13, 1998 
Table of Contents

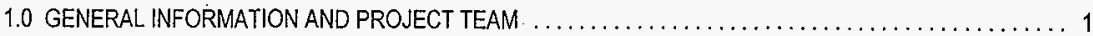

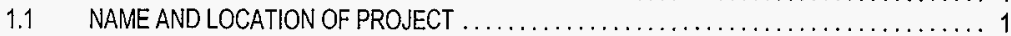

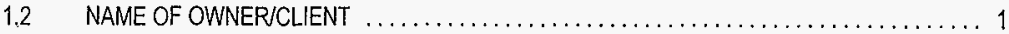

1.3 NAME OF THE BUSINESS OF THE PROJECT TEAM MEMBERS AND MAILING ADDRESS . . 1

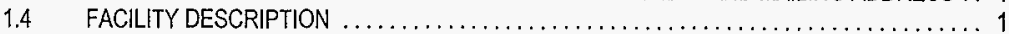

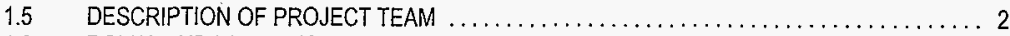

1.6 ROLES AND RESPONSIBILITIES $\ldots \ldots \ldots \ldots \ldots \ldots \ldots \ldots \ldots \ldots \ldots \ldots, \ldots \ldots, \ldots \ldots$

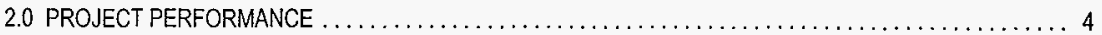

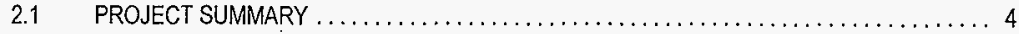

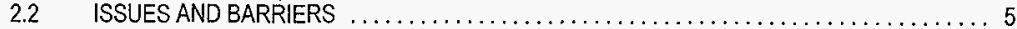

2.3 SPECIAL MANAGEMENT METHODS $\ldots \ldots \ldots \ldots \ldots \ldots \ldots \ldots \ldots \ldots \ldots \ldots \ldots, \ldots \ldots \ldots$

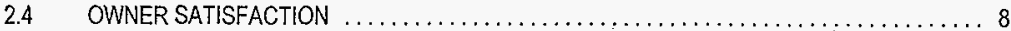

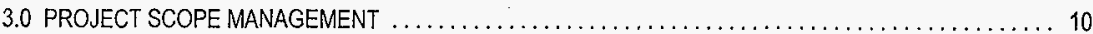

$3.1 \quad$ PROJECT CONCEPT $\ldots \ldots \ldots \ldots \ldots \ldots \ldots \ldots \ldots \ldots \ldots \ldots \ldots \ldots \ldots \ldots \ldots, 10$

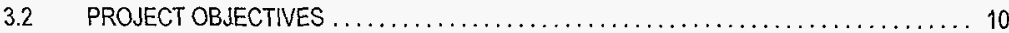

3.3 PROJECT SCOPE AND RESULTS $\ldots \ldots \ldots \ldots \ldots \ldots \ldots \ldots \ldots \ldots \ldots \ldots \ldots \ldots \ldots$

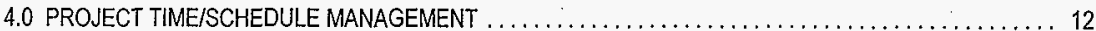

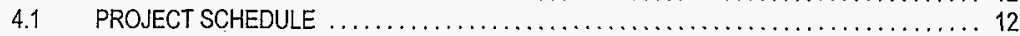

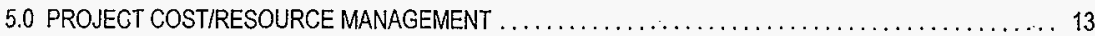

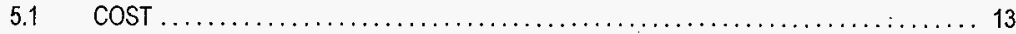

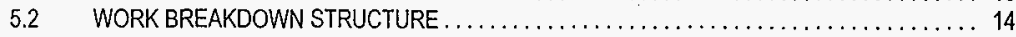

5.3 BASELINE CHANGE CONTROL $\ldots \ldots \ldots \ldots \ldots \ldots \ldots \ldots \ldots \ldots \ldots \ldots \ldots \ldots \ldots$

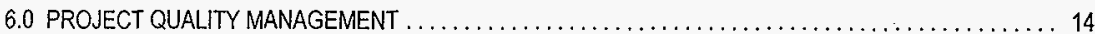

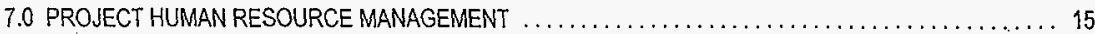

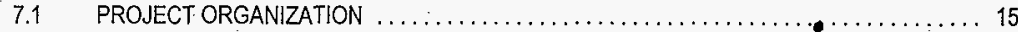

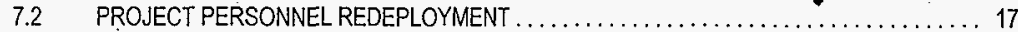

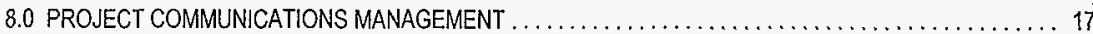

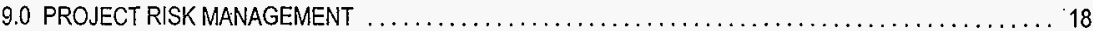

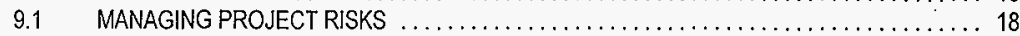

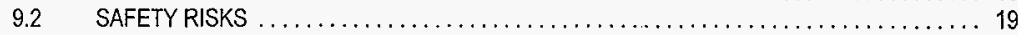

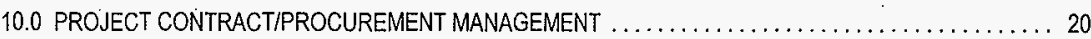

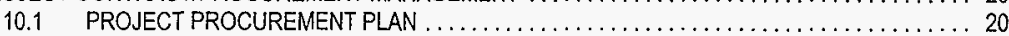

10.2 MAJOR SUBCONTRACTED PROJECTS $\ldots \ldots \ldots \ldots \ldots \ldots \ldots \ldots \ldots \ldots \ldots \ldots \ldots \ldots \ldots \ldots, 20$

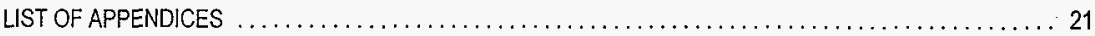


HNF-2249, Rev. 0

\subsection{GENERAL INFORMATION AND PROJECT TEAM}

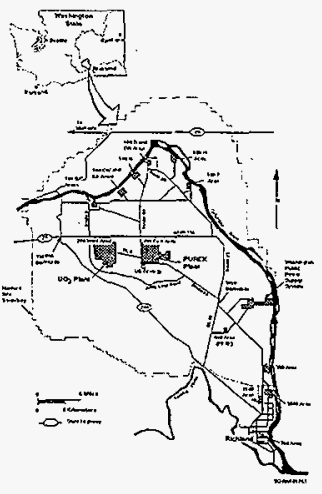

The PUREX plant is located in the southeast corner of the 200 East Area in the center of the 560 square mile U.S. Department of Energy's Hanford Site in southeastern Washington State. The UO, plant is located in the southeast corner of the 200 West Area.

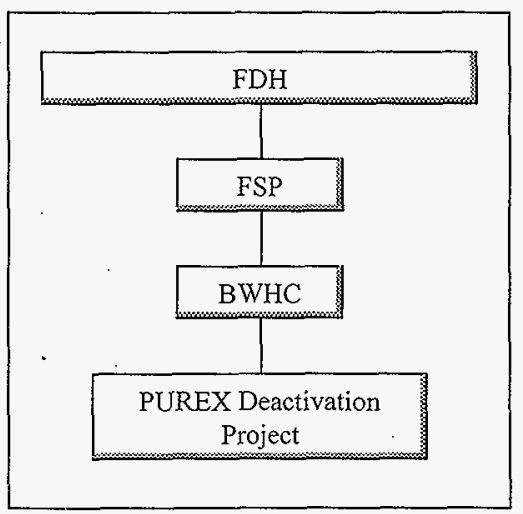

\subsection{NAME AND LOCATION OF PROJECT}

Plutonium Uranium Extraction (PUREX)/Uranium Trioxide $\left(\mathrm{UO}_{3}\right)$ Deactivation Project, U.S. Department of Energy (DOE) Hanford Site, Richland, Washington.

\subsection{NAME OF OWNER/CLIENT}

U.S. Department of Energy, Richland Operations Office (RL), Office of Facility Transition, Transition Programs Division.

\subsection{NAME OF THE BUSINESS OF THE PROJECT TEAM MEMBERS AND MAILING ADDRESS}

The PUREXUUO ${ }_{3}$ Deactivation Project was a subproject to the Facility Stabilization Project of the Project Hanford Management Contract (PHMC). Fluor Daniel Hanford, Inc. (FDH) is the Management and Intregation (M\&I) contractor for the PHMC. B\&W Hanford Company (BWHC) operates the Facility Stabilization Project for FDH. The mailing address is:

B\&W Hanford Company

P.O. Box 1200 MSIN S6-15

Richland, Washington 99352

\subsection{FACILITY DESCRIPTIÓN}

\subsubsection{PUREX}

From 1955 through 1990 , PUREX provided the Hanford Site with nuclear fuel reprocessing capability. Piutonium recovered at PUREX was shipped to the Hanford Plutonium Finishing Plant for further processing or storage for defense purposes. PUREX operated in sequence with the $\mathrm{UO}_{3}$ plant, which converted the PUREX liquid uranyl nitrate hexahydrate product to solid $\mathrm{UO}_{3}$ powder. 


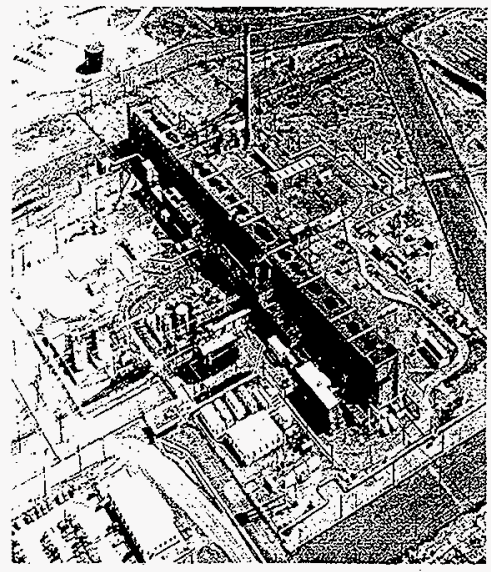

PUREX deactivation was completed on May 9, 1.997 (15 months ahead of schedule), for a total cost of $\$ 147$ million, \$75 million under budget.
PUREX is a reinforced concrete structure 1,005 feet long, 119 feet wide at its maximum and 100 feet high with about 40 feet below grade. The plant consists of three main structural components; 1) a thick-walled concrete canyon in which the radioactive processing equipment is contained, 2) service galleries which provide utilities, chemical, and laboratory services, and 3) an annex that houses control rooms, offices, laboratories, and building ventilation services.

The PUREX process chemically removed cladding (aluminum and zirconium) from fuel elements supplied by Hanford's defense reactors. The decladded fuel elements would then be dissolved in nitric acid. The acid solution was processed through a solvent extraction system which separated the uranium and plutonium from waste products.

\subsection{2 $\mathrm{UO}_{3}$}

The $\mathrm{UO}_{3}$ plant is located on the DOE Hanford Site in the 200 West Area approximately 7 miles west of PUREX. The $\mathrm{UO}_{3}$ plant was constructed in 1944 for plutonium processing and subsequently modified in 1956 for uranium processing. The facility converted the liquid uranyl nitrate hexahydrate product from PUREX into uranium oxide powder and nitric acid.

The uranium oxide powder was shipped offsite for conversion to uranium metal for nuclear

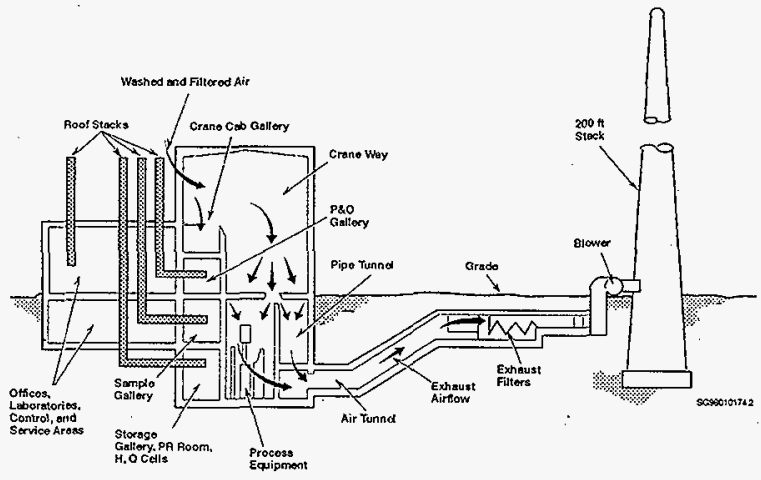
reactors and the nitric acid was recycled back to PUREX.

\section{5}

\section{DÉSCRIPTION OF PROJECT TEAM}

Hanford is a 560 square mile site built as part of the Manhattan Project to provide material to the United States nuclear weapons programs. The facilities on the Hanford Site are owned by the DOE and operated by various contractors. The DOE-Headquarters line responsibility for the

PUREXUOO $_{3}$ Deactivation Project was the Environmental Management Office of Nuclear Material and Facility Stabilization (EM-60), and field 


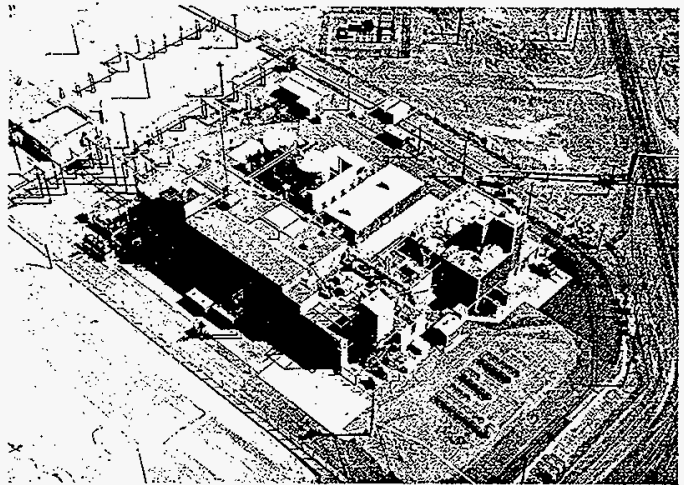

The $\mathrm{UO}_{3}$ plant was deactivated as part of the PUREX/UO $\mathrm{O}_{3}$ Deactivation Project. responsibility for the project was the RL Office of Facility Transition, Transition Programs Division.

When the PUREX and $\mathrm{UO}_{3}$ plants were shutdown, DOE managed the plants through a Management and Operations (M\&O) contract with Westinghouse Hanford Company (WHC). WHC began the deactivation of the PUREX and $\mathrm{UO}_{3}$ plants under the M\&O contract. On October 1, 1996, the contract changed from an M\&O under WHC to a M\&I under $\mathrm{FDH}$. The contract is referred to as the PHMC. The PHMC was competitively bid and WHC was replaced with Fluor Daniel Hanford, Inc.. The PHMC is divided into several major projects. The PUREXUO Deactivation Project was assigned to the Facility Stabilization Project.

\subsection{ROLES AND RESPONSIBILITIES}

DOE-Headquarters. The Office of Environmental Management, Nuclear Material and Facility Stabilization (EM-60) was responsible for overall approval of the PUREXUOO ${ }_{3}$ Deactivation Project. An EM-60 project manager was assigned to the project to act as a single point of contact for DOEHeadquarters. Primary responsibilities included:

- Approve DOE-Headquarters milestones and project funding.

... major facilities at Hanford.
This is a landmark process . . . if we would have had this type of process at other chemical processing facilities, we wouldn't have a lot of sites on the Superfund list."

$$
\begin{array}{r}
-- \text { Doug Sherwood, } \\
\text { U.S. Environmental Protection } \\
\text { Agency }
\end{array}
$$

"... the process which is in our TriParty Agreement ... lays out how we will go through decommissioning . 
“. . . lots of achievements . . took place in this project; the reduction of mortgage, a huge recycling effort, $a$. project done under budget and ahead of schedule . . and . . the team work that took place from day one ... I urge you to make this experience a model for all the complex."

--Moses Jarayssi, Washington State Department of Ecology
- Ensure compliance with applicable DOE orders, directives and regulatory requirements.

- Coordinate approval of project documentation in RL.

Contractor(s). The PUREX/UO ${ }_{3}$ Deactivation Project was initiated by the Westinghouse Hanford Company in October 1993 and completed by B\&W Hanford Company in May 1997. Consistent with DOEHeadquarters and $\mathrm{RL}$, the operating contractor designated one project manager as the single point of contact for the project. Some of the primary responsibilities of the contractor project manager included:

- Implement worker health and safety programs.

- Manage and control the project baselines.

- Perform surveillance and maintenance and deactivation work.

\subsection{PROJECT PERFORMANCE}

\section{"The deactivation of PUREX} provided an opportunity to demonstrate a new way of doing business built on trust, respect and early involvement of all stakeholders ... with common goals and objectives. As a result of this effort, we can model and/or build on this process for future facilities here at Hanford as well as elsewhere in the nation."

--Tom Tebb, Washington State Department of Ecology

\subsection{PROJECT SUMMARY}

At the end of 1992, the PUREX and $\mathrm{UO}_{3}$ plants were no longer necessary for the defense needs of the United States. Although no longer necessary, the plants were very costly to maintain in their postoperation state. The DOE embarked on a deactivation strategy for these plants to reduce the costs of providing continuous surveillance of the. facilities and their hazards and maintaining the various utility and support systems. Deactivation of the PUREX and $\mathrm{UO}_{3}$ plants was estimated to take 5 years and $\$ 222.5$ million and result in an annual surveillance and maintenance cost of \$2 million.

Deactivation of the PUREXUUO 3 plants officially began on October 1,1993 . The deactivation completion date of May 9, 1997, was 15 months ahead of the original schedule and $\$ 75$ million under the original cost estimate. The annual cost of surveillance and maintenance of the plants was reduced from $\$ 34$ million to less than $\$ 1$ million. 


\subsection{ISSUES AND BARRIERS}

Scope Changes. PUREX has two storage tunnels permitted for dangerous waste storage attached to the facility. During 1996, deactivation crews received 17 shipments of highly radioactive waste from the Hanford 324 Laboratory (operated by the Pacific Northwest National Laboratory) for placement into the PUREX storage tunnel number 2 , the first time in history the tunnels had been used for non-PUREX waste. This activity was required to meet regulatory compliance requirements for the 324 Laboratory and was not related to $\mathrm{PUREX}_{\mathrm{U}} \mathrm{O}_{3}$ deactivation. The activity was performed flawlessly, well below the acceptable levels of radiation exposure to the PUREX deactivation crews and on schedule to prevent Washington State Department of Ecology (WDOE) compliance actions against the 324 Laboratory. Impacts to the PUREX/UO ${ }_{3}$ Deactivation Project schedule were eventually made up.

Project Specifications. A fundamental question that the project had to address was, "How do you know when the project is complete?" A systematic and controlled approach for proceeding from existing conditions to a safe and economic set of final conditions (end points) was needed to answer the question. Without a method to determine the end points, the project could be subject to significant scope and cost creep as the project attempted to meet ambiguous unrealistic or unneeded objectives.

Therefore, the project used proven system engineering tools to develop and implement end point specifications. The end point specifications method is used to translate the broad project objectives into explicit goals that are readily understood by workers. The deactivation end points are essentially analogous to the design specifications for a construction project. The PUREXUUO ${ }_{3}$ Deactivation Project had a total of 2,525 end points.

The end point methodology developed for the PUREX $\mathrm{OO}_{3}$ Deactivation Project is endorsed by the DOE and oversight agencies such as the Defense Nuclear Facilities Safety Board and the WDOE. The end point process is currently being applied to a wide range of DOE projects across the nation.

Technical Challenges. Deactivation of the $\mathrm{PUREXJO}_{3}$ plants was initiated with some uncertainty regarding the removal of critical hazards at PUREX such as plutonium and uranium solutions, uranium-contaminated nitric acid, spent $\mathrm{N}$ Reactor and Single Pass Reactor fuel, and contaminated organic solutions. Aggressive management of these critical issues by the Troika, creative thinking by the technical staff and near flawless execution by field work teams led to improved technical solutions and schedule accelerations over the original baseline. For instance, the original baseline called for the treatment of nearly 200,000 gallons of nitric acid and the packaging of 6,000 gallons of mixed plutonium-uranium metal solutions into 250-300 waste drums for disposal. The ultimate disposition of the nitric acid was to recycle it to a nuclear facility in England (with the recovered uranium returned to the United States). The plutonium-uranium metal solutions were blended with various flush solutions and transferred to the Tank Waste Remediation System at Hanford. These two technical solutions alone resulted in a $\$ 38$ million cost savings, a 10 month schedule improvement over the original baseline, and 
a reduction in the volume of waste which otherwise was destined for the near capacity underground storage tanks of 250,000 gallons.

Contract Change. The change in the DOE Hanford contract on October 1, 1996, resulted in the Facility Stabilization Project being transferred from WHC to Fluor Daniel Hanford, Inc. (FDH) and B\&W Hanford Company (BWHC). The PUREX deactivation project director remained with the outgoing contractor and left the project on October 1, 1996. To complicate matters further, an early retirement had been offered to coincide with the contract changeover. Nearly ten percent of the project staff, including one of the project's senior managers, retired on October 1 , 1996. The FDH/BWHC management team worked very hard with the customer (RL) and the remaining project team at PUREX to ensure that this transition was seamless. The project director's deputy took over as the project manager and the project staff was reshuffled to fill the void created by the early retirements. No new personnel were brought onto the project team.

\section{Metrics}

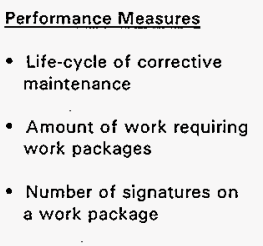

- Actual hours in the field

\subsection{SPECIAL MANAGEMENT METHODS}

The key to the ultimate success of the PUREXUOO Deactivation Project was the implementation of several unique management methods. It was recognized from the outsef that the many of the challenges facing the management team were one of a kind and had never been addressed. The special management methods are briefly described below.

\subsubsection{Troika}

Inherent in any DOE project is the involvement and shared responsibility of three primary organizations: 1) DOE-Headquarters, 2) the DOE field office (in this case $\mathrm{RL}$ ), and 3) the contractor. In an attempt to streamline decision making and ensure proper involvement and communication, an arrangement, eventually coined the "Troika," was established. The Troika consisted of one project manager from each of the three organizations. Although each of the three project managers' responsibilities differed, they functioned as a group throughout the life of the project to effectively and efficiently guide the execution of the deactivation activities.

\subsubsection{Reengineering}

One of the most dramatic special management methods employed during the $\mathrm{PUREXJO}_{3}$ Deactivation Project was reengineering. Although the redesigned business processes and organization were implemented with only 21 months left on the project schedule, the results were dramatic. The project schedule was shortened by five months, saving an estimated $\$ 13$ million. The number of managers fell from 26 in September 1995 to 6 at implementation. And the number of signatures required for a work. package fell from 14 to 7 . Despite the acceleration of the schedule, reduced management, and fewer authorizing signatures, the safety of the workers improved as evidenced by lower lost/restricted work day cases. 


\subsubsection{Public Involvement}

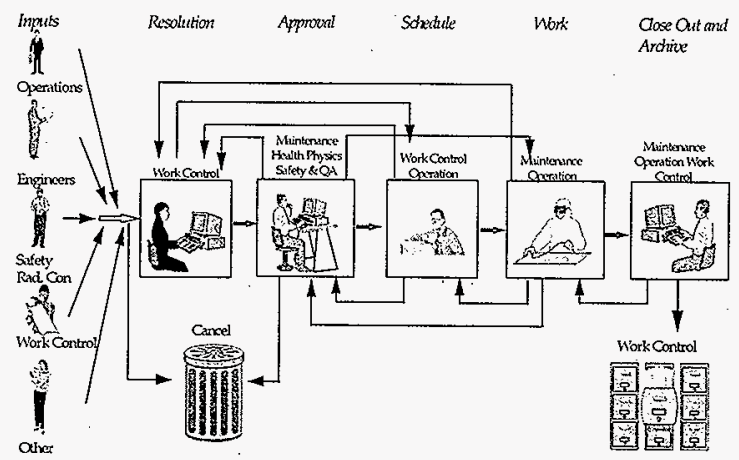

Work Control Process before Reengineering

Due to the high profile nature of the PUREXUO ${ }_{3}$ Deactivation Project and the significance of the hazards and risk reduction being undertaken, communication and participation with the public was imperative. Several public meetings were conducted to provide a forum for the important dialogue regarding the key decisions of the project. The mutual trust and understanding of issues which evolved during these sessions proved invaluable to the ultimate disposition of many of the hazardous materials. Enlisting support for the PUREX deactivation project by public interest groups helped resolve stakeholder opposition to the return of spent nuclear fuel to Hanford's K Basins and the shipment of contaminated nitric acid to England. The values of the public and interest groups were woven into the project plans for dispositioning these materials and resulted in cooperative and cost effective results.

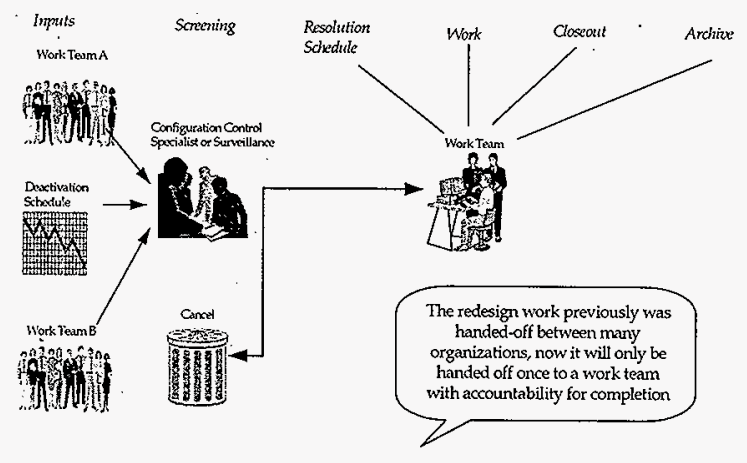

Work Control Process after Reengineering

\subsubsection{Comprehensive Communications}

The role of the PUREX and $\mathrm{UO}_{3}$ plants in the history of the United States' nuclear weapons program created an appetite for information beyond what would be expected for a typical project. Tours, media events and interviews, all employee meetings, newsletters, public meetings, and video updates were all vehicles used by the management team to meet these local, national, and international communications challenges. 
HNF-2249, Rev. 0

". . . being able to manage a project of this complexity and at the same time save $\$ 78$ million and shave a one great accomplishment."

--Al Alm, Assistant Secretary for Environmental Management U.S. Department of Energy year and a half off the schedule is

\subsubsection{Safety Management}

The PUREXUUO ${ }_{3}$ Deactivation Project developed and used a number of safety management techniques to protect the public, environment, and project workers. Examples of techniques developed and used included multi-discipline work teams, a Job Hazards Analysis tool, Preliminary Hazards Screen/Assessment for selecting hazard analysis techniques, and Task Based Hazard Screening and Analysis.

\subsubsection{Independent Technical Experts}

One of the primary PUREXJUO ${ }_{3}$ Deactivation Project objectives was to apply lessons learned from commercial nuclear experience. Several senior level, technical experts with extensive commercial nuclear experience, such as the clean up of Three Mile Island Unit 2 and other projects, were made available through DOE-Headquarters for independent consultation. These independent technical experts were consulted throughout the PUREXIUO Deactivation Project for their unique technical and managerial insights and strategic approaches.

\subsection{OWNER SATISFACTION}

The PUREXIUO ${ }_{3}$ Deactivation Project exceeded the expectations of the DOE in demonstrating the benefits of deactivation. Real, significant risk reduction was accomplished while reducing the annual mortgage costs from approximately $\$ 34$ million to less than $\$ 1$ million.

Several recognition awards were presented to the PUREXVOO ${ }_{3}$ Deactivation Project including:

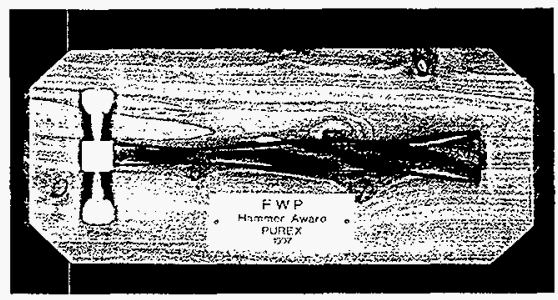

- Vice-President Gore's Golden Hammer Award for reinventing government;

-. the 1986 National Pollution Prevention Award;

- Waste Management 1996 Best Technical Poster Session-Transfer of Contaminated Nitric Acid to England;

- inclusion into DOE's recent "Highlights of the Past 20 years" publication.

Additionally, the DOE has formed a program for forwarding the processes, techniques, and strategies 
HNF-2249, Rev. 0

Table 1. List of Technical Information Exchanges/Meetings

\begin{tabular}{|c|c|}
\hline January 30,1995 & Fort St. Vrain \\
\hline February 1995 & Waste Management 1995 \\
\hline July 20,1995 & $\begin{array}{l}\text { Idaho National Engineering } \\
\text { Laboratory }\end{array}$ \\
\hline September 28, 1995 & $\begin{array}{l}\text { Savannah River Site Resource } \\
\text { Evaluation 8oard }\end{array}$ \\
\hline October 3-4, 1995 & $\begin{array}{l}\text { Rocky Flats Site/Savannah River } \\
\text { Site. }\end{array}$ \\
\hline October 10, 1995 & Oak Ridge National Laboratory \\
\hline November 14,1995 & Savannah River Site Reengineering \\
\hline May $20-23,1996$ & $\begin{array}{l}\text { American Society of Mechanical } \\
\text { Engineers, Short Course on } \\
\text { Deactivation of Nuclear Facilities for } \\
\text { Long Term Safe Storage, Denver, } \\
\text { Colorado }\end{array}$ \\
\hline Febsuary 1996 & $\begin{array}{l}\text { Waste Management 1996, awarded } \\
\text { best poster/paper }\end{array}$ \\
\hline March 6-7, 1996 & $\begin{array}{l}\text { Rocky Flats Site/Savannah River } \\
\text { Site }\end{array}$ \\
\hline April 22-23, 1996 & West Valley Demonstration Site \\
\hline July & P2 Conference \\
\hline Juily $7-12,1996$ & West Valley Demonstration Project \\
\hline July $29-31,1996$ & Rocky Flats Site \\
\hline August $4-5,1996$ & Rocky Flats Site \\
\hline August 13-14, 1996 & West Valley Demonstration Project \\
\hline November 20-21, 1996 & Rocky Flats Sile \\
\hline
\end{tabular}

which were developed during the PUREXUO Deactivation Project to the rest of the nation's nuclear defense facilities.

In a prepared statement for the PUREX closing ceremonies read by DOE Assistant Secretary Al Alm, Secretary of Energy Federico Peña congratulated the PUREX team for the extraordinary success in completing the deactivation ahead of schedule and under budget. He stated, "This is not only a milestone for Hanford. It is a milestone for the nation. The PUREX deactivation meets President Clinton's commitment to nuclear non-proliferation: It is also a national model for efficiency and innovation."

\subsubsection{Transferring Lessons Learned}

The PUREXUUO ${ }_{3}$ Deactivation Project was established as a model or pilot for demonstrating the risk reduction and cost savings achievable by deactivating a facility. Lessons learned from the project have been published in the PUREX $\mathrm{NO}_{3}$ Facilities Deactivation Lessons Learned History (HNF-SP:1147, Rev. 2).

Numerous technical exchange meetings were held to disseminate the lessons learned information (see Table 1).

Safety management lessons learned have been published in a bulletin titled integrating Safety and Health During Deactivation - With Lessons Leamed from PUREX (DOE/EH-0486), by the DOE Office of Environment Safety and Health.

In an attempt to effectively transfer the lessons learned from the PUREXUOO ${ }_{3}$ Deactivation Project, a deactivation handbook was prepared. The handbook, titled, Facility Deactivation Guide, Methods and Practices Handbook (DOE/EM-0318), provides detailed guidance in the development of end point specifications and other key deactivation processes and strategies. The handbook has been used by many facilities in conjunction with direct consultation from personnel involved with the PUREX/UO Deactivation Project.

Utilizing a core group of former PUREXUUO Deactivation Project employees, DOE has set up a program to jumpstart other DOE complex deactivation projects based upon the experience learned at 
PUREX. The recently formed Facility Stabilization and Environmental Restoration (FASTER) Services organization is supporting projects at Brookhaven
National Laboratory, Savannah River Site, Oak Ridge Site, West Valley Site, and Rocky Flats Environmental Technology Site.

\subsection{PROJECT SCOPE MANAGEMENT}

\subsection{PROJECT CONCEPT}

At the time the Cold War came to an end, the PUREX and $\mathrm{UO}_{3}$ plants were being maintained in a standby (ready to restart) condition. With no need for defense material, the PUREX and $\mathrm{UO}_{3}$ plants no longer had an operating mission. A December 21, 1992, termination letter was sent from the DOEHeadquarters to the RL directing the shutdown and terminal cleanout of the PUREX and $\mathrm{UO}_{3}$ plants. The objective was to put the PUREX and $\mathrm{UO}_{3}$ plants in a safe, stable condition that could be maintained while the DOE fully developed a formal decontamination and decommissioning plan.

The typical life cycle of nuclear facilities like the PUREX and $\mathrm{UO}_{3}$ plants is construction, operation, and decommissioning, where decommissioning is the final disposition of the facility. Decommissioning is a time consuming and costly process. The PUREXNUO Deactivation Project defined an interim step called deactivation. This innovative step resulted in minimizing the cost of subsequent surveillance and maintenance. Due to the extensive decommissioning costs for large facilities, the time between the end of deactivation and the beginning of decommissioning can be decades. The primary focus of deactivation is minimizing the cost of surveillance and maintenance by eliminating/reducing residual hazards, minimizing operating systems, and collapsing the administrative infrastructure.

Prior to PUREX, the DOE (and its predecessors) had extensive experience with large construction projects, but had very little experience with deactivation or applying project management discipline to deactivation activities. With PUREX it was the DOE's intention to model deactivation within a project framework. In the December 21, 1992, PUREX termination letter, Deputy Assistant Secretary Bixby indicaled, "This project has the potential for establishing the basis for the Department's future deactivation program."
In early 1993, several workshops and meetings were held to kickoff the PUREXUUO ${ }_{3}$ Deactivation Project. These meetings established the roles and responsibilities of the "Troika," developed the regulatory and safety framework for the project, crystallized the project objectives, and supported development of a Project Management Plan. Participation included the DOE (Headquarters and $\mathrm{RL}$ ), the contractor, various regulatory agencies from Washington and Oregon, and outside technical experts.

\subsection{PROJECT OBJECTIVES}

The PUREX/UO ${ }_{3}$ Deactivation Project objectives were developed to support the DOE's Office of Facility Transition and Management's overall goal of developing switt, uniform methods for deactivation of similar facilities. The project objectives were:

- Establish a safe and environmentally secure configuration of the plants (no active internal functions or equipment within confinement) and retain that configuration for a 10-year horizon.

Ensure worker health and safety throughout the life of the project. Maintain a high degree of emphasis foward worker health and safety by applying a graded approach to implementing safety controls, providing adequate worker training, and a strong emphasis on conduct of operations.

- Achieve a yearly cost target of $\$ 2$ million/year at turnover.

- Implement cost effective, innovative approaches to ensure the required safety envelope is defined and maintained during deactivation. 
- Achieve compliance with environmental, safety, and health codes and standards during deactivation.

- Involve stakeholders in the development of the PUREX/UO ${ }_{3}$ Deactivation Project Management Plan and ensure continued involvement throughout the life of the project.

- Transition the workforce out of the PUREX and $\mathrm{UO}_{3}$ plants through redeployment or outplacement.

Apply lessons learned from commercial deactivation experience.

- Establish the PUREXUUO ${ }_{3}$ Deactivation Project as a pilot for canyon facilities.

\subsection{PROJECT SCOPE AND RESULTS}

The PUREXUOO ${ }_{3}$ Deactivation Project scope is discusșed in the following sections.

\subsubsection{Removal of High-Risk Materials}

Plutonium/Uranium Solutions. Product solutions remained in the plant after the last operating campaign as feed for an anticipated restart. The
6,000 gallons of solution contained 9 kilograms of plutonium and 5 metric tonnes of uranium. This solution was originally intended to be packaged into waste drums. However, the engineering staff worked extensively with site personnel to demonstrate that the most cost effective and least hazardous method of disposal would be to blend the material with facility flush solutions for disposal in the Hanford underground storage tanks.

Contaminated Nitric Acid. After the last operating campaign at $\mathrm{UO}_{3}$, nearly 200,000 gallons of uraniumcontaminated nitric acid were recovered and shipped to PUREX for storage. The plant actively marketed the acid throughout the United States with no response. However, a facility in England expressed an interest in obtaining the PUREX acid. Months of negotiations (with a variety of local and national stakeholders) and preparations ended with the facility in England receiving the acid and returning recovered uranium to the United States. A total of 52 shipments of acid occurred over a period of 11 months. The activity required fabrication of special shipping containers for the acid in accordance with international shipping regulations, an Environmental Assessment to meet the requirements of the National Environmental Policy Act, public meetings in the potential ports of departure from the east coast (the port of Norfolk, Virginia, eventually was chosen for loading of the acid containers on ships), and special transportation requirements for trucking the acid across the United States.

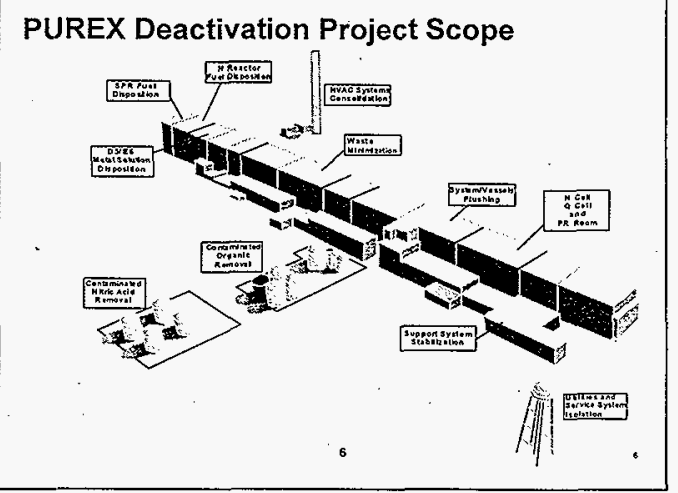

Contaminated Organics. 21,000 gallons of radioactively contaminated organic (Tri-butyl Phosphate in kerosene) solution required disposition. The material was classified as a listed waste in the state of Washington, which limited treatment and disposal alternatives. Eventually, a licensed waste incinerator facility in Oak Ridge, Tennessee, was found to take the organic. Special transportation requirements similar to the nitric acid were needed to ship the organic to Tennessee. Five shipments were required to dispose of the PUREX organic.

Plutonium Gloveboxes. Kilograms of plutonium nitrate and oxide were 
removed from the PUREX plutonium gloveboxes in order to deactivate the gloveboxes. Final lay up of the gloveboxes included applying a fixative to the inner surfaces of the gloveboxes to immobilize the remaining plutonium contamination. This technique was first used at Hanford's 308 facility. PUREX crews assisted the 308 facility crews to gain experience in the technique before deactivating the PUREX gloveboxes.

Spent Fuel. Approximately 3 metric tonnes of single. pass reactor fuel remained in a fuel storage pool inside PUREX. The fuel had been underwater for over 20 years. The fuel basket integrity was suspect and overpacks were designed to retrieve the fuel for transfer back to Hanford's K Basins for storage. In addition to the single pass reactor fuel, 38 pieces of $N$ Reactor spent fuel ( $\sim 0.5$ metric tonnes) were on the canyon floor of PUREX. Special tools had to be fabricated to pick the fuel pieces off the floor, wash the fuel, and load the fuel for shipment.

Chemical Inventory. In addition to the nitric acid and organic solutions, PUREX shut down with an inventory of over 3 million pounds of bulk and specialty chemicals. About 2.5 million pounds of this inventory was recycled by selling or giving the materials away. Less than 500,000 pounds was disposed of as waste.

\subsubsection{Configuration Changes to Achieve Low Cost Surveillance and Maintenance}

- Consolidated 4 operating ventilation zones and 11 exhaust stacks into one heating, ventilation, and air conditioning (HVAC) zone with one exhaust stack.

- Reduced air discharges from 123,000 cubic feet per minute to 40,000 cubic feet per minute.

- Terminated all five liquid effluent discharges to the environment from about 10,000 gallons per minute to zero.

- Consolidated electrical loads and installed dedicated substation external to facility.

- Installed a central system to provide control and monitoring of the modified HVAC system.

\subsection{PROJECT TIME/SCHEDULE MANAGEMENT}

\subsection{PROJECT SCHEDULE}

The PUREX/UO ${ }_{3}$ shutdown order on December 21, 1992, initiated the conception of the overall deactivation strategy which produced a framework for the deactivation project. The deactivation officially started on October 1, 1993. The schedule objective was to complete the deactivation of the PUREXUO plants by July 31,1998 , and the actual completion date of deactivation was May 9,1997 . A table of key dates and actual completions is included in the appendix.

\subsubsection{Schedule Management}

The schedule baseline was documented in the Level 1 - Master Project Schedule. The master schedule included Tri-Party Agreement, DOE-Headquarters,
$R L$, and Westinghouse Hanford Company/B\&W Hanford Company milestones.

The schedule and schedule control process included an integrated network capable of producing a critical path logic for the entire project for analysis and reporting. Periodic reviews by DOE-Headquarters and RL utilized the network capabilities and data reports to analyze project status.

\subsubsection{Schedule Performance}

The baseline duration of the PUREXUO Deactivation Project to complete the necessary deactivation activities while safely performing surveillance and maintenance on the facility was expected to be 5 years. 


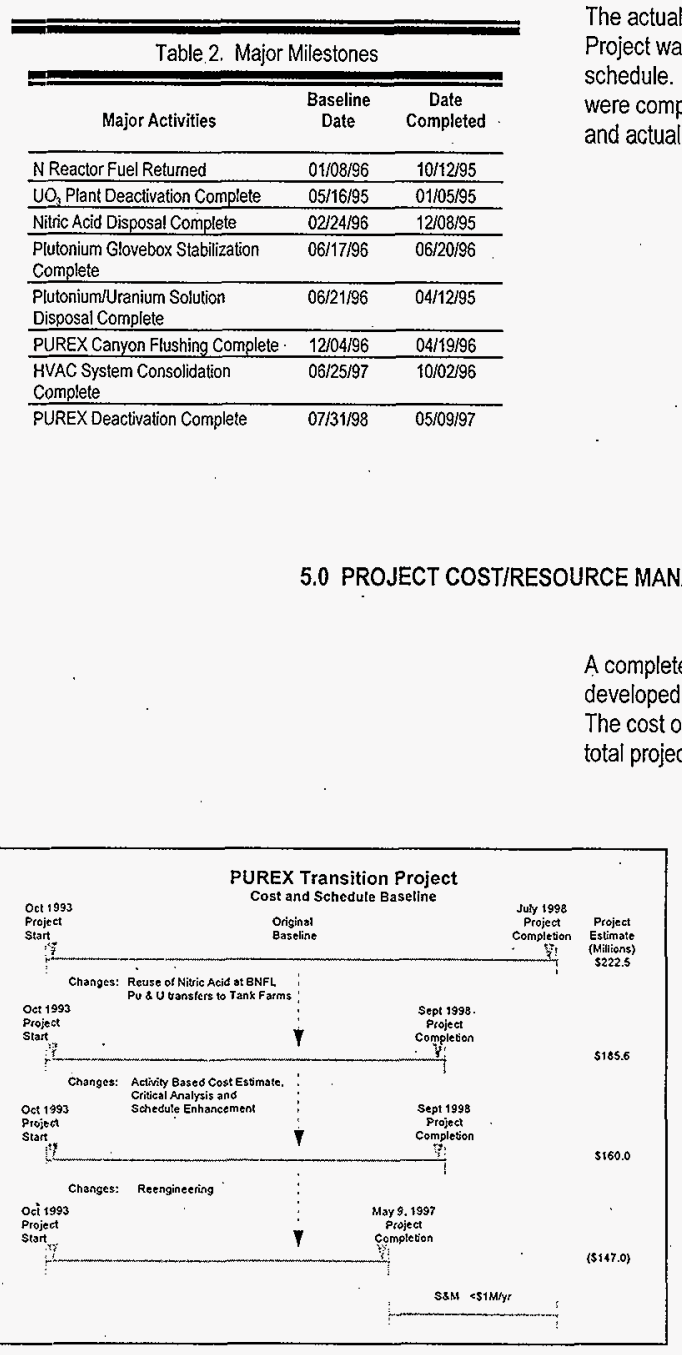

\section{$5.1 \quad \cos T$}

When the PUREX/UO ${ }_{3}$ Deactivation Project began in October 1993, the baseline cost was $\$ 222.5$ million. The surveillance and maintenance component was budgeted at $\$ 165$ million. The deactivation activities were budgeted at $\$ 57.5$ million. At the completion of the project, the surveillance and maintenance was expected to cost approximately $\$ 2$ million per year.

The actual total cost of the PUREX/UO Deactivation Project was $\$ 147.0$ million$\$ 75$ million under budget. The resulting surveillance and maintenance is less than $\$ 1$ million annually. 


\subsection{WORK BREAKDOWN STRUCTURE}

The work breakdown structure (WBS) effectively defined the project into distinct deliverables. The project work efforts were organized by Project Summary WBS (PSWBS) and Contract WBS

(CWBS). DOE-Headquarters reviewed and approved the PSWBS. The contractor was responsible for the CWBS.

\section{DEACTIVATION IS A GOOD INVESTMENT PUREX/UO3}

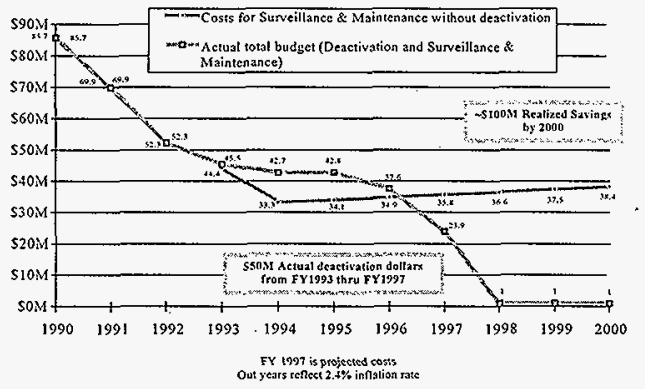

The PSWBS included five maijor expense categories and a plant and capital equipment category. There were multiple CWBS elements under each expense category.

\subsection{BASELINE CHANGE CONTROL}

Changes to the project cost, schedule, and technical baselines were classified Class 0, Class I, Class II, or Class III, according to the magnitude of the impact. The change classifications were used to identify the approval authority.

Class 0 changes required DOE-Headquarters approval; Class I changes required RL approval; Class II and III changes required contractor approval.

All project changes were strictly controlled and processed in accordance with approved change control procedures.

\subsection{PROJECT QUALITY MANAGEMENT}

The PUREX and $\mathrm{UO}_{3}$ plants are considered nuclear facilitities under federal regulations and as such must maintain a quality assurance $(Q A)$ program in accordance with 10 CFR 830.120 (Nuclear Safety Management, Quality Assurance Requirements). Company QA procedures and implementation plans were built to ensure compliance with the federal statutes. Those procedures and plans were implemented at PUREX through the PUREXUUO Quality Assurance Program Plan (QAPP).
The primary objective of the QAPP was to provide a user-friendly document that identified the ten $Q A$ criteria outlined in 10 CFR 830.120 along with references to facility procedures implementing those criteria. The objective was for all individuals involved in the project to know and understand which quality criteria applied to their work and what their role was in implementing the criteria through the facility procedures. 


\begin{tabular}{l}
$\begin{array}{c}10 \text { Basic Criteria of the } \\
\text { Quality Program }\end{array}$ \\
$\begin{array}{l}\text { Management Criteria } \\
\text { 1. Quality Assurance Program } \\
\text { 2. Personnel Training and } \\
\text { Qualifications } \\
\text { 3. Quality Improvement } \\
\text { 4. Documents and Records } \\
\text { Performance Criteria } \\
\text { 5. Work Processes } \\
\text { 6. Design } \\
\text { 7. Procurement } \\
\text { 8. Inspection and Acceptance Testing } \\
\text { Assessment Criteria } \\
\text { 9. Management Assessment } \\
\text { 10. Independent Assessment }\end{array}$ \\
\hline
\end{tabular}

Project progress and completion was measured in terms of the deactivation end points. A key element of $Q A$ was a practice whereby the contractor responsible for facility decontamination and decommissioning (Bechtel Hanford Incorporated in the case of the PUREXUOO ${ }_{3}$ plants), would negotiate the project end points and approve the final completion of each individual end point, thus guaranteeing an independent review of deactivation activities.

\subsection{PROJECT HUMAN RESOURCE MANAGEMENT}

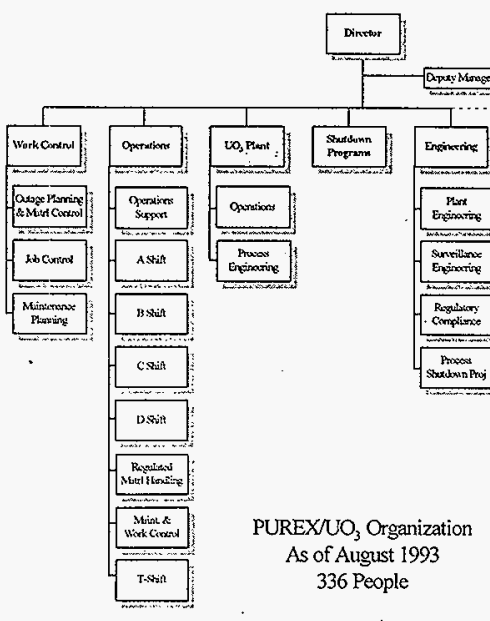

\subsection{PROJECT ORGANIZATION}

At the inception of the PUREX $\cup \mathrm{O}_{3}$ Deactivation Project, the organization was staffed with over 300 former production workers who operated the two plants. Deactivation was initiated with this production-orientated structure. $\mathrm{UO}_{3}$ deactivation, being a small unit within the overall projegt, was successful in this arrangement. However, the nature of deactivation at PUREX after the first year was that deactivation was not a project but a continuation of operations practices. After the first year the organization was further projectized from operation and engineering functions into a Surveillance project (Operations and Engineering responsible for the facility nuclear safety envelope) and a Deactivation project (Operations and Engineering responsible for deactivation activities). 


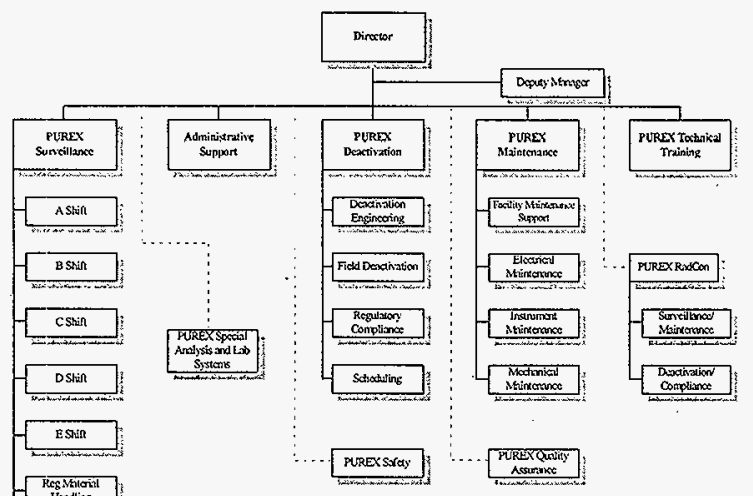

PUREX $/ \mathrm{UO}_{3}$ Organization As of November 1994 260 People
Facility Maintenance and Radiological Control were matrixed to Surveillance and Deactivation under the project director.

When further projectization of the organization occurred, the $\mathrm{UO}_{3}$ plant deactivation was nearly complete and no changes were made to the $\mathrm{UO}_{3}$ organization. $\cup_{3}$ deactivation was completed in January 1995. The further projectization of PUREX reduced the focus from operations practices and more towards a project culture.

An even larger paradigm shift occurred when PUREX was chosen as the Hanford Site's reengineering pilot in August 1995. Westinghouse Hanford Company had embarked on an effort to reengineer its activities at Hanford and after completing extensive planning, a search was conducted for the right facility to pilot the effort. PUREX was chosen after completion of a self-evaluation and an independent review by the company's reengineering sponsors. Supported by the site facilities team, site leadership, Human Resources, and the facility director, a team made up of key RL, PUREX exempt, and PUREX craft employees was chartered to redesign the core processes, organization, and management systems for the redesigned from a blank sheet of assessment, $Q A$, and scheduling
PUREX Organization As of January 1996 226 People PUREX deactivation project. The work management, surveillance, and configuration control processes were paper. Work planning, risk were adjusted to line up with the

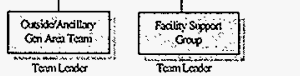
new core processes. An organizational change was
necessary to fully capitalize on the streamlined 
processes and to create the culture change desired for the project. The project and functional organizations (i.e., Surveillance, Deactivation, Work Control, Maintenance, and Radiation Control) were eliminated and a team structure was incorporated into the new design. Procedures were changed and employees were provided training on teaming and the redesigned processes. All positions in the new organization were filled through a selection process, and the redesign was implemented in January 1996. The result was the project pioneered more change in the last two years than was envisioned. Employees' job scopes were expanded and new roles and responsibilities were taken on by all.

Implementation of reengineering cost the PUREX project approximately $\$ 1$ million and preparations for implementation caused some activities to fall up to 45 days behind schedule. Within three months of implementation, the schedule had been made up. By the end of the 1996 fiscal year (over 8 months after implementation) the project had been accelerated two months. Using the reengineered work processes and the team based organization over the last 16 months of the project accounted for a 5 month schedule acceleration and savings of over $\$ 13$ million.

\subsection{PROJECT PERSONNEL. REDEPLOYMENT}

One of the original objectives of the Project was to transition the workforce out of the project. Unlike a typical construction staff which is used to work ramping down, the vast majority of the project staff 's experience was from production and had never faced the challenge of working themselves out of a job.

Early in the project a simple redeployment model was developed with each individual linked to a likely redeployment date based upon the project schedule. The model was continuously updated and the redeployment process was aggressively communicated. Approximately $90 \%$ of the original project staff was successfully redeployed into other positions. The end result was that the project staff knew where they were going before their work ramped down, allowing them to concentrate on their assignments and not be distracted by worrying about their job future.

\subsection{PROJECT COMMUNICATIONS MANAGEMENT}

Regular project status meetings were held with the various project entities. The project staff met weekly with the project director to discuss performance, issues, and impacts. The project director met monthly with the RL to review costs, schedule performance, and issue resolution. The project director and the RL met quarterly with the DOEHeadquarters. These quarterly meetings were typically roll ups of the monthly meetings. The meetings alternated between face-to-face meetings (either in Richland or Washington, D.C.) and video conferences.

The deactivation of the PUREX and $\mathrm{UO}_{3}$ plants generated a large interest base. As symbols of the Cold War and the first major DOE plants in the complex to go through a formal deactivation process, this project generated significant local, regional, national, and international interest.

Regulatory Meetings. Monthly meetings were held with the Washington State Departments of Ecology and Health to review project progress and discuss issues.

Public Interest. Updates to the Hanford Advisory Board (a local public interest group) were conducted on a regular basis. These updates were usually of a short general overview concentrating on major hazard reductions and held in a public forum.

Tours. Over 150 tours of PUREXUO ${ }_{3}$ were conducted between the shutdown order and the closing ceremony marking the end of deactivation. These tours ranged from a single individual to groups of over thirty. Some of the more notable guests were U.S. Senator Patty Murray, U.S. Representative Richard "Doc" Hastings, DOE Assistant Secretary Tara O'Toole, DOE Assistant Secretary AI Alm, the United Nations Ambassadors negotiating the Fissile Material Cutoff Treaty, and representatives of the French, British, South Korean, and Russian atomic agencies. 
Media. Four major media events with local and regional television, radio, and print media were held during the life of the project. In addition numerous other media interviews were conducted throughout the life of the deactivation project.

Videos. The project documented much of the deactivation project on video for record purposes. The project produced three videos for project public relations. The first video, completed in late 1994, was a ten minute overview of PUREX/UO ${ }_{3}$ deactivation. The second video, completed in early 1996, updated deactivation progress and included statements from customers and public interest groups. The third video, completed in 1996, was a history of PUREX and deactivation as told by employees.

All Employee Meetings. Monthly meetings were held for the project employees. At its inception, a typical meeting would include the managers of the various sub-projects discussing project progress, the deputy project manager discussing redeployment activities, and finally a project overview by the project director followed by a question and answer period. Feedback from the employees after the first few meetings indicated a change was needed to generate more interest in the meetings. An employee group began the organization of the meetings and added special guests such as representatives from public interest groups and regulators, and individual work team members rather than managers giving status of their activities.

People Center. The PUREXJUO ${ }_{3}$ People Center was a physical location in the PUREX complex set aside as an additional communications vehicle. Staffed by project volunteers and company Human Resources personnel, employees could get help looking for redeployment opportunities, assistance in resume preparation, or answers to questions or rumors that they had heard. The People Center also put out a twice-a-month newsletter communicating issues that the People Center staff was working on, communicate deactivation highlights, focus on a specific work group, or provide updates on redeployment.

\subsection{PROJECT RISK MANAGEMENT}

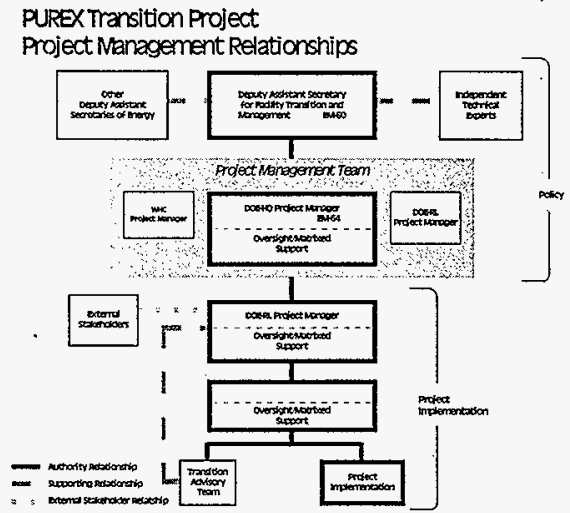

A project in the nuclear industry such as the PUREXUO ${ }_{3}$ Deactivation Project carries two general risks: The risk of not completing the project and the risks to the public and workers.

\subsection{MANAGING PROJEST RISKS}

Timely Decisions. Since the PUREX deactivation was the first time a facility as complex as PUREX was deactivated, the project received high visibility and interest from the federal, state, and local governments, stakeholders, Indian Nations, and the public. The situation where many people are involved with different perspectives leads to a risk of extended discussion about issues and confusion as to who makes final decisions. Therefore, management agreed to identify an individual from the DOE-Headquarters, an individual from the $R \mathrm{~L}$, and the project director to act as the final decision making body on decisions or issues. These individuals (referred to as the Troika) were also responsible for ensuring that approvals or 
decisions from other groups within their organizations were performed in a timely manner. This group also ensured that decisions and issues outside of the Troika's control were done so that the field work and the overall deactivation schedule were not impacted.

Consistent Funding. Losing part or all of the project budget over the duration of the project was considered a high risk to the successful completion of the project. The emphasis in Congress of a balanced budget put all DOE budgets under attack annually. The members of the Troika took responsibility to protect the funds during the duration of the project. Conscience efforts were made to demonstrate and repori progress so that budget decision makers were kept informed. Since the regulators and special interest groups supported deactivation, a concerted effort was made to maintain communication with these groups to keep them informed of the progress of deactivation. These groups then informed Congress and DOE-Headquarters of their interest in seeing that the project maintain funding.

\section{Flush Canyon Vessels}

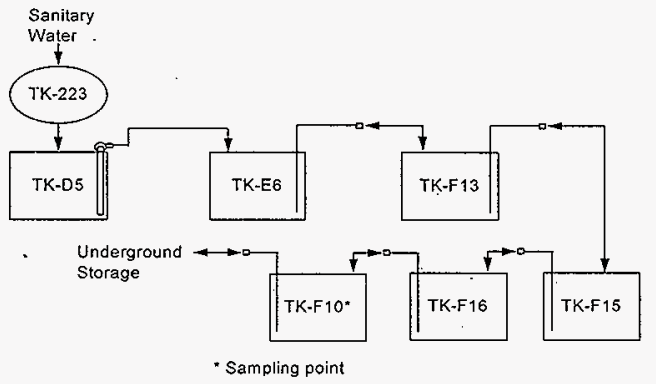

Interface with the Regulators. As a permitted dangerous waste facility, PUREX was regulated under the Resource Conservation and Recovery Act (RCRA). Invoking a shutdown order for the PUREX and $\mathrm{UO}_{3}$ plants triggered actions under various regulatory requirements. Most significant, RCRA requires closure of a dangerous waste facility within 180 days of shutdown. This was not possible for the PUREX and $\mathrm{UO}_{3}$ facilities. Consequently; the contractor and DOE entered into negotiations with the Washington State Department of Ecology and U.S. Environmental Protection Agency to develop a regulatory framework for the deactivation of the PUREX and $\mathrm{UO}_{3}$ plants. Key to this process was the negotiation of enforceable milestones under the Hanford Federal Facility Agreement and Consent Order, commonly referred to as the Tri-Party Agreement. Other regulatory drivers included the National Environmental Policy Act, the Clean Air Act, and the National Emission Standards for Hazardous Air Pollutants.

Throughout deactivation, the project teamed with regulators to develop a number of innovative solutions. These innovations minimized thousands of gallons of liquid wastes and significantly reduced solid waste volume. One significant innovation was to flush the process vessels in loops or series and take a sample from the final vessel to demonstrate the flush had met the criteria to remove dangerous waste. Flushing vessels in loops instead of individually greatly minimized the flush water required and the subsequent waste sent to the underground storage tanks.

\subsection{SAFETY RISKS}

The project utilized a graded approach to safety associated with deactivation activities. Workers demonstrated the enhanced work planning process and pioneered the development of the Job Hazards Analysis process during PUREX deactivation. This approach to work planning and execution received Vice-

President Gore's Golden Hammer award for reinventing government in August 1997. The process is being applied at other facilities on the Hanford site 
and is the centerpiece of DOE's Integrated Safety Management process.

The Integrated Safety Management process implemented at PUREX produced several important outcomes, including:

- improved worker safety, as verified by lostworkday statistics;

- more systematic and thorough evaluations of potential hazards associated with proposed work activities;

- decreased costs to the project in safety documentation development;
- improved employee morale, especially among those involved in the hazards assessment process; and

- improved quality of Unreviewed Safety Question determinations.

One of the most significant changes resulting from the PUREX integrated safety strategy was the ability to evaluate the hazards of proposed deactivation activities in a graded manner. The PUREX Preliminary Hazards Screening/Assessment process was used to select hazard analysis techniques appropriate for specific project tasks.

\subsection{PROJECT CONTRACT/PROCUREMENT MANAGEMENT}

\subsection{PROJECT PROCUREMENT PLAN}

The planning and design of the PUREXUO Deactivation Project was primarily performed by the PUREXUUO ${ }_{3}$ project staff, with support from Westinghouse Hanford Company (WHC) /B\&W Hanford Company (BWHC), ICF KH, and independent technical experts.

Due to the nature of the work, cleanout and stabilization activities were performed by WHC/BWHC staff. Activities defined as Davis-Bacon Act work was performed by ICF KH staff and their subcontractors.

\subsection{MAJOR SUBCONTRACTED PROJECTS}

Installation of new electrical substation.

Significant reduction in power needs for the PUREX facility prompted the need to reconfigure the electrical distribution system. A contract to provide a new electrical substation was established. The new substation was a modular, skid-mounted unit equipped with its own fire detection and suppression systems and HVAC system.

Installation of new surveillance and monitoring control systems. A new control system was needed for the reconfigured PUREX HVAC system: A contract was written to provide the necessary control and communication systems to operate and control the post-deactivation PUREX HVAC system.
Disposal of Contaminated Organic Solution. Approximately 21,000 gallons of contaminated organic solvent (Tri-butyl Phosphate in kerosene) was shipped to a licensed waste incinerator facility in Tennessee. The facility burned the solution in a cogeneration facility to generate electricity.

Transport of Contaminated Nitric Acid to England. A unique contract was set up between WHC and British Nuclear Fuels, Limited to transport approximately 200,000 gallons of contaminated organic to a reprocessing plant in Sellafield, England, for reuse. The material required being trucked from the Hanford site to the east coast of the United States, shipped to Sellafield, England, across the Atlantic Ocean, and finally taken by rail to the reprocessing plant operated by British Nuclear Fuels, public limited company. 
HNF-224.9, Rev. 0

\section{LIST OF APPENDICES}

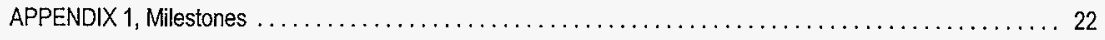

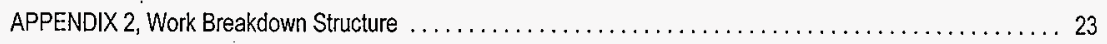

APPENDIX 3 , Statement of Secretary of Energy Frederico Peña $\ldots \ldots \ldots \ldots \ldots \ldots \ldots \ldots \ldots \ldots \ldots \ldots$

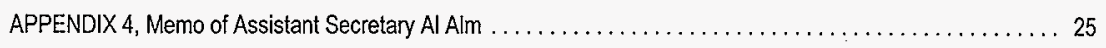

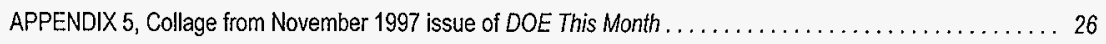


APPENDIX 1

\begin{tabular}{|c|c|c|}
\hline Milestone Description & $\begin{array}{l}\text { Milestone } \\
\text { Date }\end{array}$ & $\begin{array}{c}\text { Completion } \\
\text { Date }\end{array}$ \\
\hline Deactivation Cost Estimate Submitted & $10 / 31 / 93$ & $10 / 31 / 93$ \\
\hline $\mathrm{UO}_{3}$ Plant Phase I Deactivation Completed & $03 / 15 / 94$ & 02/28/94 \\
\hline E-F11 Concentrator Demonstration Completed & 03/16/94 & $02 / 25 / 94$ \\
\hline Tank D5/E6 Engineering Study Completed & $04 / 08 / 94$ & $01 / 28 / 94$ \\
\hline $\mathrm{UO}_{3}$. Process Condensate Discharge Discontinued & $09 / 26 / 94$ & $09 / 22 / 94$ \\
\hline Single-pass Fuel Returned & $12 / 04 / 95$ & $10 / 12 / 95$ \\
\hline Żirconium Heel Stabilization Completed & $10 / 19 / 94$ & $05 / 06 / 94$ \\
\hline $\mathrm{UO}_{3}$ SNM Final Accountability Reconciled & $10 / 19 / 94$ & $10 / 19 / 94$ \\
\hline $\mathrm{UO}_{3}$ Cooling Water Discharge Discontinued & $12 / 21 / 94$ & $11 / 28 / 94$ \\
\hline Project Safety Basis Package Submitted & $04 / 11 / 95$ & $01 / 31 / 95$ \\
\hline N Reactor Fuel Returned & $01 / 08 / 96$ & $10 / 12 / 95$ \\
\hline $\mathrm{UO}_{3}$ Plant Deactivation Completed & 05/16/95 & $01 / 05 / 95$ \\
\hline Nitric Acid Disposal Completed & $02 / 24 / 96$ & $12 / 08 / 95$ \\
\hline Plutonium Glovebox Stabilization Completed & $06 / 21 / 96$ & 06/20/96 \\
\hline Plutonium-Uranium Solution Disposal Completed & $07 / 22 / 96$ & $04 / 12 / 95$ \\
\hline PUREX Canyon Flushing Completed & $12 / 04 / 96$ & 04/19/96 \\
\hline Tank Farm Waste Lines Isolated & $12 / 04 / 96$ & $07 / 02 / 96$ \\
\hline PR Room Deactivation Completed & 03/19/97 & $04 / 23 / 96$ \\
\hline Sample Gallery Deactivated & $04 / 22 / 97$ & 07/24/96 \\
\hline PUREX SNM Final Accountability Reconciled & 05/16/97 & $09 / 22 / 96$ \\
\hline Pipe \& Operating Gallery Deactivated & $06 / 02 / 97$ & $06 / 13 / 96$ \\
\hline PUREXUOO ${ }_{3}$ Plant Surveillance \& Maintenance Plan Completed & $06 / 24 / 97$ & $05 / 16 / 96$ \\
\hline HVAC System Consolidation Completed & $06 / 25 / 97$ & $10 / 02 / 96$ \\
\hline Ancillary Buildings Deactivated & $06 / 01 / 98$ & 05/09/97 \\
\hline PUREX Liquid Effluent Discharge Discontinued & 06/17/98 & 05/09/97 \\
\hline PUREX Deactivation Completed & 07/31/98 & 05/09/97 \\
\hline
\end{tabular}


HNF-2249, Rev. 0

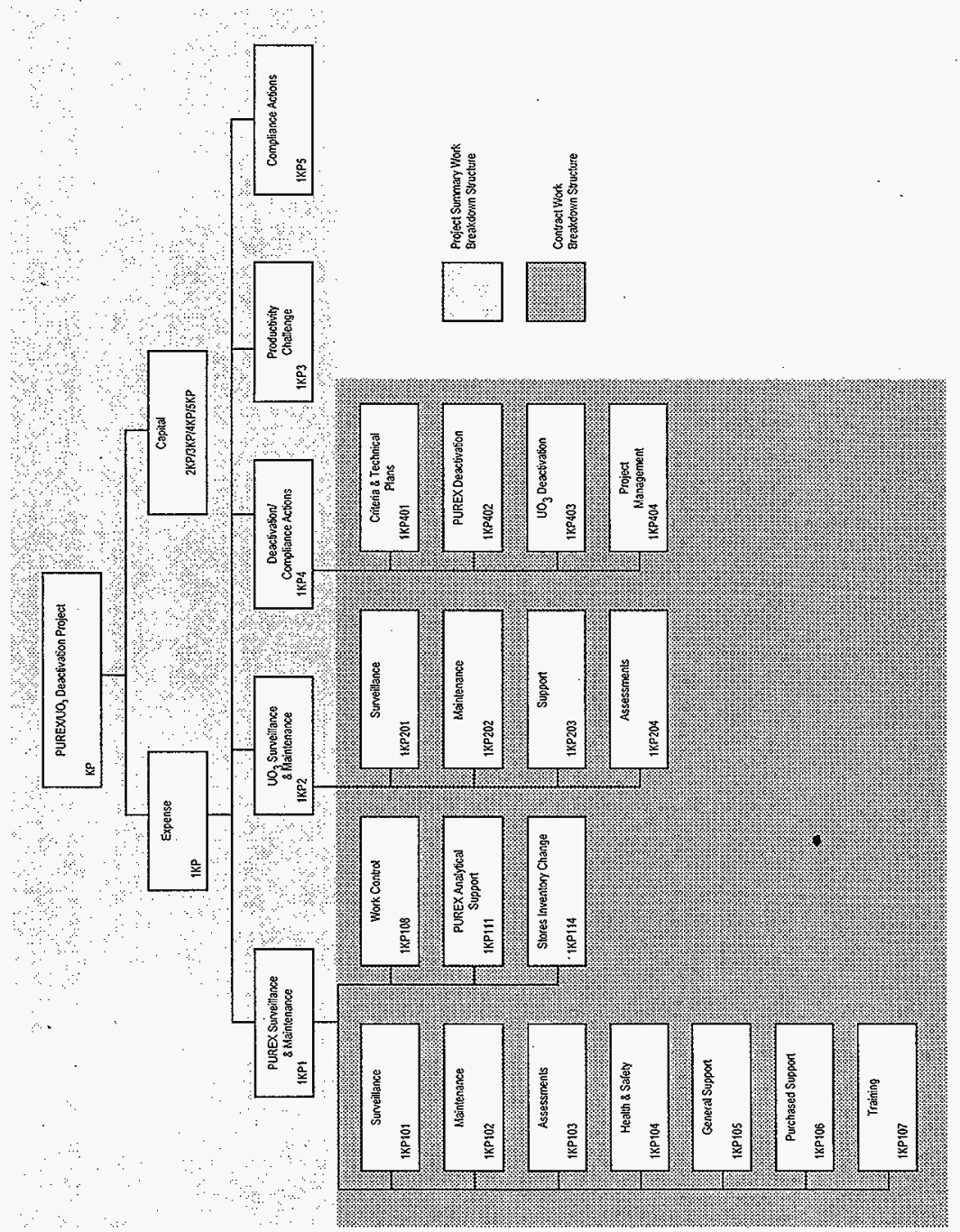


NEWS MEDIA CONTACTS:

Carmen MacDougall, 202/586-4940

Anne Elliott - Matthew Donoghue, 202/586-5806
FOR IMMEDIATE RELEASE

June 20, 1997

\section{Statement by \\ Secretary of Energy Federico F. Peña \\ On PUREX Deactivation \\ June 20. 1997}

Today, we close another door on the Cold War era with the deactivation of the most visible symbol of Hanford's 45-year defense mission. I congratulate you for completing this historic milestone for nonproliferation -- deactivation of the Plutonium Uranium Extraction, or PUREX, facility. More importantly, I congratulate you for your extraordinary success in reaching this goal more than one year ahead of schedule and nearly $\$ 78$ million under budget.

This is not only a milestone for Hanford. It is a milestone for the nation. The PUREX deactivation meets President Clinton's commitment to nuclear non-proliferation. It is also a national model for efficiency and innovation.

One reason for such success has been the cooperation of several groups. The Department of Energy and our contractors worked closely with the U.S. Environmental Protection Agency, the Washington State Department of Ecology, the Hanford Advisory Board, Indian tribes and our stakeholders. This group focused on a common goal and met it with flying colors.

The lessons learned in deactivating PUREX are being applied at one of Hanford's oldest facilities, the World War II-era B Plant. I regret that I cannot thank you in person, but I look forward to even greater achievements as you apply your experience at the B Plant and share your knowledge with other sites throughout the country. 


\section{memorandum}

DAT: JUL $\mid 19997$

REPLYTO

ATTN OF: EM-50

sUaAecti Congratulations on the Completion of PUREX Deactivation.

To: Lloyd Piper, Acting Manager, Richland Operations Office

Congratulations on the Hay 9, 1997, deactivation of PUREX. This is a substantive demonstration to the American pubijc that the Department is wisely managing the funds entrusted to us to minimize risk to the public and the environment.

The Rlchland team was highly creative in addressing several key areas, including in particular the disposition of contaminated nitric acid. The partnerships between regulators, stakeholders, contractors and Federal staff opened doors for regulatory innovation and improved methods of doing business, resulting in opportunities for cost savings. Your innovative thinking resulted in accelerated deactivation, saving millions of dollars which can now be used to complete other necessary cleanup projects. The Richland team's willingness to take on programatic risk and senior management's willingness to reward, not penalize, risk taking have resuited in a notable success. $\because$

Lessons learned from the first significant deactivation project in the Department, will be invaluable. Completion of the 2,500 end points in this effort demonstrated the management skllis and technical competency necessary to quickly and efficiently close an obsolete facility that would otherwise pose risks to workers, the environment, and eventually the public. As the first major facility deactivation, it is a symbol to our elected leadership of EM's commitment to closing factlities, visibly demonstrating to the American people that their government can produce results, at low cost, and be successful in the cleanup of colo war legacy wastes.

The men and women who have been a part of the PUREX deactivation have set a high standard for the rest of tho Department. I greatly appreciate their hard work, dedication and commitment and look forward to celebrating with them at the Jurie 20 ceremony. I wish them the best as they continue on other projects, and expect that their example will encourage continued development of innovatiye approaches by other deactivation projects.
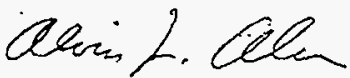

Alvin L. Alm

Assistant Secretary for Environmentat Management

cc: John Hagoner, Brookhaven

Peter Knollmeyer, AHF-RL. 

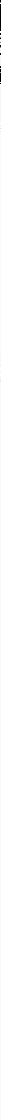


\section{CORRESPONDENCE DISTRIBUTION COVERSHEET}

Author

R. W. Bailey, 373-4999
Addressee

Ms. J. A. Diediker, PMI
Correspondence No.

BWHC-9851393

Subject: 1997 PROJECT OF THE YEAR AWARD NOMINATION PROPOSAL

\section{DISTRIBUTION}

\begin{tabular}{lccc}
\hline Approval & Nate & Location & w/att \\
\hline & Central Files & $\mathrm{X}$ \\
& Document Process Center & A3-94 & $\mathrm{X}$
\end{tabular}

B\&W Hanford Company

FASTER Services

S6-15

$\mathrm{X}$

W. M. Heer

H5-31

$\mathrm{X}$

B. Oldfield

R3-56

$\mathrm{X}$

RWB File/LB

Fluor Daniel Hanford, Inc.
L. J. Olguin
N1-26
$\mathrm{X}$
G. W. Reddick
$\mathrm{N} 1-26$
$\mathrm{X}$

Rust Federal Services of Hanford Inc.

W. G. Jasen

T4-52

$\mathrm{X}$

U.S. Department of Energy. Richland Operations Office

P. M. Knollmeyer

A5-11

$\mathrm{X}$

J. E. Mecca

R3-79

$\mathrm{X}$

L. E. Rogers

R3-79

$\mathrm{X}$ 
February 13, 1997

BWHC-9851393

Ms. J. A. Diediker, Program Manager

PMI Project of the Year Award Program

Tri-Cities/Columbia Basin Chapter

Project Management Institute

3520 Port of Benton Blvd., Suite 221

Richland, Washington 99352

Dear Ms. Diediker:

1997 PROJECT OF THE YEAR AWARD SUBMITTAL

Thank you for the invitation to submit the PUREX Deactivation Project as a candidate for the Tri-Cities/Columbia Basin Chapter of the Project Management Institution, Project of the Year competition. Attached is the original and five copies of our submittal.

Please contact me if you have any questions or need further information. I can be reached on 373-4999.

Sincerely,

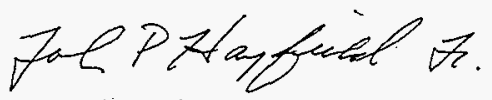

R. W. Bailey, Director

FASTER Services

$\mathrm{kmf}$

Attachments (6) 


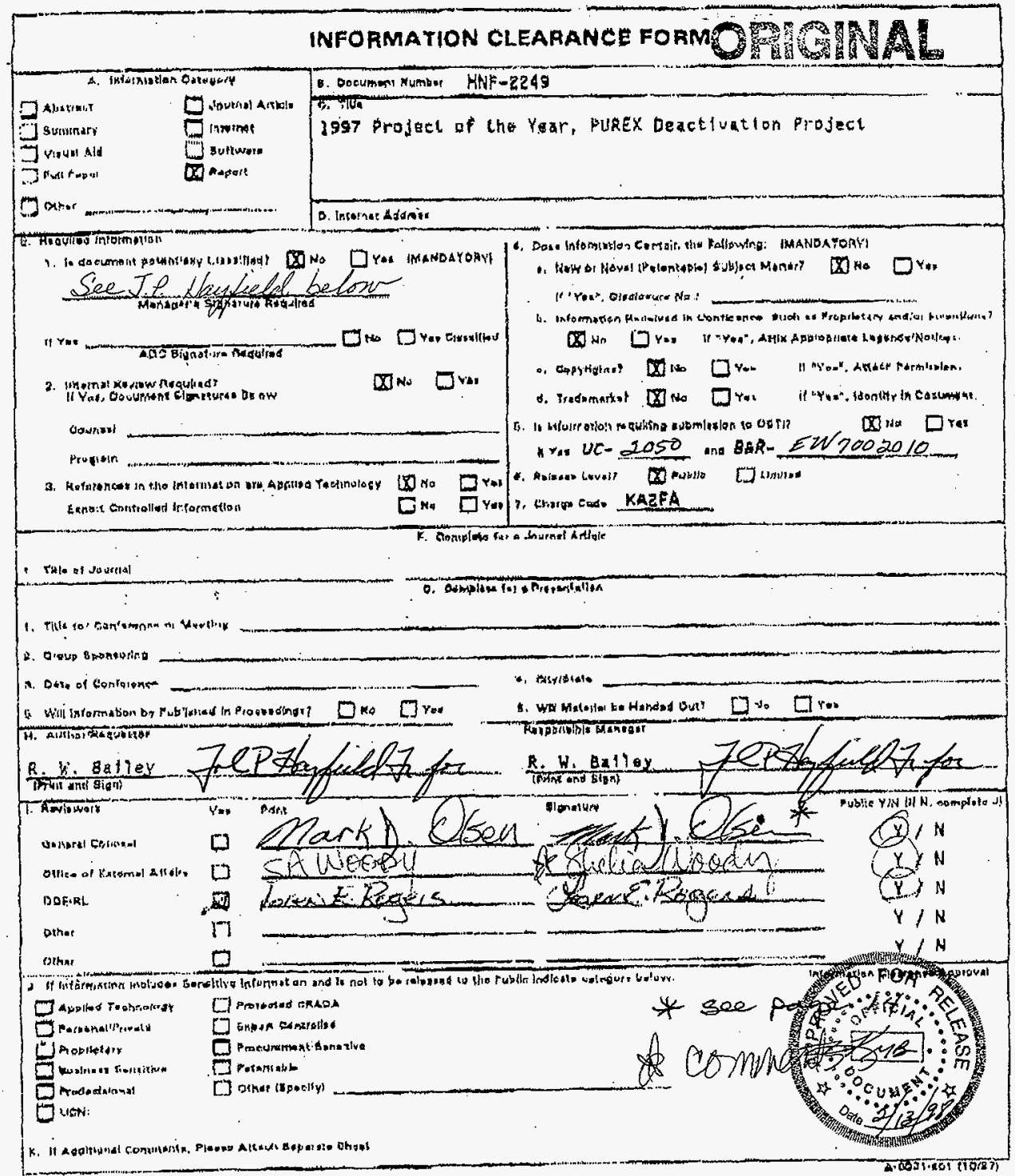

